IZA DP No. 92

The Rate of Return to Private Schooling

Robert E. Wright

December 1999 


\title{
The Rate of Return to Private Schooling
}

\author{
Robert E. Wright \\ University of Stirling, Scotland, CEPR, London \\ and IZA, Bonn
}

\section{Discussion Paper No. 92 December 1999}

\author{
IZA \\ P.O. Box 7240 \\ D-53072 Bonn \\ Germany \\ Tel.: +49-228-3894-0 \\ Fax: +49-228-3894-210 \\ Email: iza@iza.org
}

This Discussion Paper is issued within the framework of IZA's research area General Labor Economics. Any opinions expressed here are those of the author(s) and not those of the institute. Research disseminated by IZA may include views on policy, but the institute itself takes no institutional policy positions.

The Institute for the Study of Labor (IZA) in Bonn is a local and virtual international research center and a place of communication between science, politics and business. IZA is an independent, nonprofit limited liability company (Gesellschaft mit beschränkter Haftung) supported by the Deutsche Post AG. The center is associated with the University of Bonn and offers a stimulating research environment through its research networks, research support, and visitors and doctoral programs. IZA engages in (i) original and internationally competitive research in all fields of labor economics, (ii) development of policy concepts, and (iii) dissemination of research results and concepts to the interested public. The current research program deals with (1) mobility and flexibility of labor markets, (2) internationalization of labor markets and European integration, (3) the welfare state and labor markets, (4) labor markets in transition, (5) the future of work, (6) project evaluation and (7) general labor economics.

IZA Discussion Papers often represent preliminary work and are circulated to encourage discussion. Citation of such a paper should account for its provisional character. 
IZA Discussion Paper No. 92

December 1999

\section{ABSTRACT}

\section{The Rate of Return to Private Schooling}

This paper examines the relationship between "school quality" and earnings in the United Kingdom. The specific focus is on evaluating the effect that private schooling has on hourly wage rates. It is well known that private (i.e. fee-paying) schools compared to state schools score higher on most measures of school quality. Therefore by comparing individuals with private schooling to those with state schooling (and controlling for other variables) it is possible to indirectly evaluate the effect of school quality. Panel data from five waves of the British Household Panel Survey are used in the analysis.

JEL Classification: I2

Keywords: Private education, school quality, earnings

Robert E. Wright

Department of Economics

University of Stirling

Stirling, Scotland

FK9 4LA

Tel: $44-1786467481$

Fax: 44-1786 467469

Email: r.e.wright@stir.ac.uk

\footnotetext{
* Much of this paper was written when the author was visiting the Swedish Institute for Social Research (SOFI) at the University of Stockholm, whose hospitality (particularly that of Anders Björklund) is gratefully acknowledged. Helpful comments were received at seminars at the Tinbergen Institute, the Universities of Stockholm, Lund, Gothenburg, Uppsala, Aberdeen and Stirling, and at a CEPR workshop held at the Studienzentrum Gerzensse, Switzerland. The author is however totally responsible for all remaining errors and shortcomings.
} 


\section{Introduction}

There is considerable debate (especially in the United States) surrounding the impact that "school quality"- expenditure, classroom size, teacher training and other educational inputs—has on an individual's short- and long-run socio-economic success. This debate began in earnest with the publication of the so-called Coleman Report in 1966 (Coleman et al., 1966) which concluded that school inputs had a negligible effect on achievement, as measured by test scores. This controversial (and somewhat surprising) finding has spawned a vast literature concerned with estimating the magnitude of school quality effects on a variety of outcomes, including test scores, high-school graduation rates, university participation and graduation rates, unemployment rates and earnings (see Moffitt, 1996). However, despite the intensity of effort, there is still little consensus on the relative importance of school quality and the debate rages on. ${ }^{1}$

One common criticism of much of this empirical research is the crude way in which school quality is often measured. For example, Card and Krueger (1992a,b) in their US studies analysed the impact of school quality on earnings at the state level. ${ }^{2}$ More specifically, they regressed individual earnings on a series of school inputs measured as state averages (e.g. student/teacher ratios, teacher wages and teacher education) and found statistically significant and large school quality effects. Betts (1995), on the other hand, regressed individual earnings on the inputs of the actual school that the individual attended, and found no statistically significant school quality effects. It could be the case that the findings reported by Card and Krueger may be driven by the highly aggregated level at which they chose to measure school quality-a

\footnotetext{
1 See for example the recent nine paper: "Symposium on School Quality and Educational Outcomes" published in 1996 in the Review of Economics and Statistics (vol. 98, no. 4, pp. 559691).

${ }^{2}$ For a thorough and convincing criticism of the Card and Krueger studies see Heckman et al. (1996).
} 
possibility demonstrated more formally by Hanushek et al. (1996) (see also Heckman et al., 1996).

With this in mind, the purpose of this paper is to examine the relationship between school quality and earnings in the United Kingdom. The specific focus is on evaluating the effect that private schooling has on earnings. It is well known that private (i.e. fee-paying) schools compared to state schools score higher on most measures of school quality. Therefore by comparing individuals with private schooling to those with state schooling (and controlling for other variables) it is possible to indirectly evaluate the effect of school quality. Panel data from five waves of the British Household Panel Survey are used in the analysis.

\section{Private Schooling in the $\mathrm{UK}^{3}$}

In the United Kingdom, fee-charging schools are sometimes referred to as "independent schools", or more traditionally (and somewhat confusingly) as "public schools". Independent schools are private schools in the sense that they receive no grants from public sources and are usually owned and managed under special trusts (i.e. not directly by the Government). Most independent schools offer a similar range of courses to state schools and enter students for the same public examinations. However, they are not obligated to teach the state-determined National Curriculum, nor do they have to comply with state-set education targets. All independent schools, however, are open to inspection and must register with the appropriate government department. These departments set various minimum standards which are enforceable by law. In this sense, independent schools are regulated (but not controlled) by the Government.

\footnotetext{
${ }^{3}$ Much of the information presented in this section was supplied by the Independent Schools Information Service (see: http://www.isis.org.uk/).
} 
Independent primary schools are of two main types: (1) Pre-preparatory-for individuals aged 2 to 7; and (2) Junior or Preparatory ("Prep")—for individuals aged 7 to 11 or 13. The title "preparatory" is used because the last two years is devoted to preparing students for the Common Entrance Examination, on which a "pass" is required for admittance to many independent secondary schools (discussed below). Independent primary schools come in a variety of formssome are privately owned and run for profit, while others are charitable foundations. They may or may not have a religious emphasis. The average class size for most schools is 15 to 20 students per teacher. There are usually three terms per academic year and the fees for the majority of these schools fall in the range $£ 600$ to $£ 1,000$ per term for ages 2 to 7 ; 950 to $£ 2,500$ per term for "day students" (i.e. not boarding) aged 7 to 13 ; and $£ 2,300$ to $£ 3,500$ per term for boarders aged 7 to 13. Independent secondary schools admit students from the age of 11 onwards. Most schools require prospective students to sit the Common Entrance Examination, but some schools set their own examinations. This examination may be taken at age 11,12 or 13 , depending on the student's "readiness". It is set centrally and marked individually by the senior school, but each school sets its own pass mark. The main academic goal of independent secondary schools is to prepare students for the series of state-set examinations which are required in order to enter higher education (e.g. "A-levels" for university education). The average class size is 20 to 25 students per teacher. There are usually three terms per academic year, with fees for most independent secondary schools falling in the range of $£ 1,300$ to $£ 2,700$ per term for female day schools; $£ 2,700$ to $£ 4,400$ per term for female boarders; $£ 1,300$ to $£ 3,200$ per term for male day schools; and $£ 2,800$ to $£ 4,600$ per term for male boarders.

From 1981 until 1997, many independent schools offered places to "promising" children whose parents can not afford the full fees through the government-funded Assisted Places Scheme. The last students to benefit from this subsidy entered secondary school in September of 
1997, since the Labour Government abolished the programme shortly after their election in May of the same year. Some schools are attempting to compensate for the loss of students by awarding more scholarships, although these scholarships rarely cover the full fees. These scholarships are usually awarded as a result of a competitive academic examination. Most schools appear to be attempting to compensate for the loss of income by increasing fees at a rate well above that of inflation (e.g. by an average of 5 per cent for the session 1998/99).

In order to avoid confusion, in the remainder of this paper, the term "private schooling" will be used to describe attendance at an independent school and the term "state schooling" will be used to describe attendance at a school that is funded by the government (i.e. not private schooling).

\section{Empirical Evidence}

\section{Model}

In an attempt to evaluate the effect that private schooling has on earnings, begin by considering the following Mincer-like (1974) earnings equation:

$$
\ln w_{i}=\alpha+\rho S_{i}+\beta_{1} \operatorname{Exp}_{i}+\beta_{2} \operatorname{Exp}_{i}^{2}+\gamma \boldsymbol{X}_{i}+\varepsilon_{i}
$$

where the subscript " $i$ " denotes the individual; "Inw" is the natural logarithm of some measure of earnings (e.g. hourly wage rate); " $S$ " is years of schooling completed; "Exp" is years of cumulative work experience; " $X$ " is a vector of "other" variables thought to determine earnings; " $\varepsilon$ " is an error term; and the remaining terms are parameters to be estimated. With this specification, $\rho=\partial \ln w / \partial S$, which can be expressed in percentage terms by applying the following simple transformation: $r=[\exp (\rho)-1] \cdot 100$. It is this quantity, " $r$ ", which is usually referred to as 
the rate of return to schooling (i.e. the percentage increase in earnings associated with an additional year of schooling).

One way to introduce school quality into the earnings relationship is to augment Eq. (1) with an interaction between schooling and school quality (see Behrman and Birdsall, 1983; Heckman et al., 1996). That is:

$$
\ln w_{i}=\alpha+\rho_{1} S_{i}+\rho_{2} S_{i} \cdot q_{i}+\beta_{1} \operatorname{Exp}_{i}+\beta_{2} \operatorname{Exp}_{i}^{2}+\gamma \boldsymbol{X}_{i}+\varepsilon_{i}
$$

where in addition to the terms defined above, " $q$ " is some measure of the "quality" of the school individual " $i$ " attended. In this model, school quality enters through the rate of return to schooling, so that the effect on earnings increases with the years of schooling completed (see Figure 1). If school quality is measured by a dummy variable that takes on a value of "1" if private school was attended and " 0 " if state school was attended, then: $\partial \ln w / \partial S_{s}=\rho_{l}$, where the subscript " $s$ " denotes state schooling; and $\partial \ln w / \partial S_{p}=\rho_{l}+\rho_{2}$ where the subscript " $p$ " denotes private schooling. Therefore, the associated rates of return to state schooling and private schooling are: $r_{s}=\left[\exp \left(\rho_{1}\right)-1\right] \cdot 100$ and $r_{p}=\left[\exp \left(\rho_{1}+\rho_{2}\right)-1\right] \cdot 100$, respectively. If school quality matters then one would expect to find that $r_{p}>r_{s}$.

$$
<<<\text { Figure } 1 \text { About Here }>>>
$$

Ordinary Least Squares (OLS) estimation of Eq. (2) will provide unbiased estimates of the rates of return to private and state schooling if (at least) two key assumptions are met. The first is that years of schooling $(S)$ is exogenous. The second is that school quality $(q)$ is also exogenous. If these two assumptions are not met, then the estimated rates of return to schooling will be 
biased, and it is difficult (if not impossible) to determine a priori the direction of this bias. ${ }^{4}$ Unfortunately, there is considerable evidence, both theoretical and empirical, suggesting that both these assumptions are unrealistic. For example, if schooling is "investment" resulting from some form of optimising behaviour, then one would expect a positive relationship between schooling and its return, implying that OLS estimates will be biased upwards. Likewise, if there are unobservable variables that are correlated with both schooling and earnings—such as "ability" and "motivation"- then OLS estimates will be biased upwards. On the other hand, if there is measurement error in schooling and/or earnings, then OLS estimates will be biased upwards. ${ }^{5}$

In the absence of "better" data, one way to attempt to deal econometrically with these problems, is to use instrumental variable (IV) techniques to "endogenise" schooling. In its simplest application, this involves searching for variables (or using natural variation in the data) that influence decisions about schooling but at the same time do not directly influence earnings. In this paper (as is described below) we use IV methods with panel data in an attempt to model this potential endogeneity.

\section{Data}

In this section, data from five waves of British Household Panel Survey (BHPS), covering the period 1991 to 1996 , are used to estimate a panel data version of the earnings equation described in Eq. (2). The BHPS is a nationally representative survey of some 5,000 households (about 10,000 individuals) from all regions of Great Britain, with the exception of the far north of Scotland. The first wave of the survey was carried out in September to December 1991, with

\footnotetext{
${ }^{4}$ See Willis (1986) for a concise discussion of the other assumptions underlying human capital earnings equations.

${ }^{5}$ It is important to point out that in most studies of the impact of school quality on earnings, including Card and Krueger (1992a,b), schooling and school quality are usually assumed to be exogenous.
} 
subsequent waves being carried out annually. Individuals interviewed in any wave are reinterviewed in subsequent waves, so the survey has a true panel element. New individuals were interviewed to replace those lost through attrition in later waves. Therefore, each of the waves, in any particular year, is a nationally representative cross-section of the British population (subject to some weighting). ${ }^{6}$

In our analysis the panel element of the BHPS is explicitly used. A balanced panel consisting of men observed in all five waves is constructed. In order to reduce the problems associated with the potential endogeneity of schooling and retirement decisions, this sample is restricted to men who are aged 25 to 54 years in Wave I (and consequently aged 29 to 59 years in Wave V). Individuals in full-time schooling and self-employment are excluded. These sample restrictions (and accounting for missing information) resulted in a sample size of 1,074 men, who are observed in employment in each of the five waves of the BHPS.

The model estimated is of the general form:

$$
\ln w_{i t}=\alpha Z_{i}+\beta \boldsymbol{X}_{i t}+\theta_{i}+\varepsilon_{i t}
$$

where: the subscript " $i$ " denotes the individual $(i=1,2, \ldots N=1,074)$; the subscript " $t$ " denotes the period $(t=1,2, \ldots T=5) ; \ln w_{i t}$ is the natural logarithm of the hourly wage rate; $Z_{i}$ is a vector of fixed covariates (i.e. variables that do not change in value over time); $\boldsymbol{X}_{i t}$ is vector of timevarying covariates (i.e. variables that do change in value over time); $\theta_{i}$ is a time-invariant individual-specific fixed effect; and $\varepsilon_{i t}$ is and error term. The fixed covariates included in Eq. (3) are: years of schooling completed $(S)$; years of schooling/private school interaction $(S \cdot q)$; and dummy variables for place of birth (4 categories). The time-varying covariates are: years of full-

\footnotetext{
${ }^{6}$ See Buck et al. (1994) for a detailed discussion of the BHPS.
} 
time work experience $(\operatorname{Exp})$ and its square $\left(\operatorname{Exp}^{2}\right)$; a dummy variable for poor health (Health); a dummy variable for being married (Married); and dummy variables for region of residence (11 categories).

The earnings variable $(w)$ is the hourly wage rate expressed in 1996 real pounds sterling and assumes an over-time premium of 50 per cent. Years of schooling $(S)$ is the number of years of full-time education completed. School quality $(q)$ takes on a value of " 1 " if the individual reported attending a "public or other private school" or a "fee-paying grammar school" and takes on a value of " 0 " other wise (i.e. attended a school financed by the state). Full-time work experience $(\operatorname{Exp})$ is constructed by assuming a weight of 50 per cent for part-time work experience. The four categories of place of birth are England, Wales, Scotland and foreign-born. Three dummy variables representing these four categories are constructed, with England being the excluded category. The poor health variable (Health) is coded "1" if the individual reports that their health over the last 12 months has been "poor" or "very poor" and coded "0" otherwise (i.e. fair, good or excellent). The married variable (Married) takes on a value of "1" if the individual is legally married and " 0 " if not (i.e. single, divorced, separated or widowed). Region of residence is defined in terms of the eleven "standard" geographic regions of Great Britain: London, Southwest, Southeast, East Anglia, East Midlands, Northwest, Yorkshire and Humberside, North, Wales and Scotland. Ten dummy variables representing these eleven categories were constructed, with London being the excluded category. Descriptive statistics for these variables are presented in Table 1.

\section{$<<<<$ Table 1 About Here $\gg>>>$}

There are two main approaches to estimating a fixed effects model (see for example, Kim and Polachek, 1994). The first is a "mean-deviation estimator", which is essentially an OLS regression obtained by subtracting each individual's mean variable value from each time period's 
observation. The second is a "first-difference estimator", which is also essentially an OLS regression which sweeps out the individual fixed effects by subtracting lagged values from each observation. One problem with applying either of these estimators to Eq. (3) is that one does not obtain an estimate of the parameters of the fixed covariates $(\alpha)$, since the impact of these variables are eliminated by the transformations that the estimators are based on. Put slightly differently, the impacts of the fixed covariates are subsumed into the individual-specific fixed effects. From the point of view of this paper, this is problematic since mean-deviation or firstdifference estimation will not yield an estimate of the rate of return to school because in our specification schooling does not vary over time.

Hausman and Taylor (1981) outline a fixed effects estimation strategy that allows for fixed covariates. Their strategy consists of two steps. In the first step, the means-deviation estimator is applied to a model that only includes the time-varying covariates:

$$
\ln w_{i t}=\beta \boldsymbol{X}_{i t}+\theta_{i}+\varepsilon_{i t}
$$

In the second step, estimates of this equation are used to construct the following model:

$$
\overline{\ln w}_{i}-\hat{\beta} \bar{X}_{i}=\alpha Z_{i}+\lambda_{i}
$$

where the bar-symbol "-"denotes the mean variable value over the $T$ periods observed (i.e. 5); the hat-symbol "^" denotes an estimated parameter value; and $\lambda_{i}=\theta_{i}+\varepsilon_{i}$. The left-hand side of Eq. (5) is in a sense a "residual" consisting of a fixed effect $\left(\theta_{i}\right)$, the composite effect of the fixed covariates $\left(\alpha \boldsymbol{Z}_{i}\right)$ and a random error component $\left(\varepsilon_{i t}\right)$. 
OLS estimation of Eq. (5) will generate parameters estimates for the fixed variables $(\alpha)$. However, OLS estimates may be biased because $\lambda_{i}$ may be correlated with the fixed covariates, $\boldsymbol{Z}_{i}$. This seems highly likely since we have strong a priori theoretical reason to believe that both schooling and school quality are endogenous (as discussed above). One way to address this problem is to employ instrumental variables (IV) techniques to estimate Eq. (5). We follow such an approach by constructing fifteen variables describing the occupation status and social class of the individual's mother and father when he was aged 14. Social class was measured as dummy variables based on the following occupation categories: "professional"; "managerial and technical"; "skilled non-manual"; "skilled manual”; "partly skilled"; "unskilled"; and "father/mother not working", along with the category: "father/mother deceased". In addition, a continuous measure of occupational status- "the Revised Cambridge Scale of Occupations"was used (see Prandy, 1980). By using these variables as the identifying instruments, we are assuming that "family background" (as defined) only affects earnings indirectly through schooling and school quality and there is no direct effect on earnings. We carried out tests described in Bound et al. (1995) which suggest that this assumption is statistically acceptable. It is also important to note that we also carried out Hausman-Wu exogeneity tests (again using family background as the identifying instruments) and the exogeneity of schooling and schooling quality is solidly rejected.

\section{Estimates}

The estimates of the wage equations are summarised in Table 2. The associated rates of return to schooling are shown in Table 3. Columns (1), (3), (5) and (7) are models that only include schooling $(S)$ while Columns (2), (4), (6) and (8) include both schooling $(S)$ and years of schooling/private school interaction $(S \cdot q)$. Columns (1) to (4) are "non-fixed effects" models, 
with OLS estimates in Columns (1) and (2) and IV estimates in Columns (3) and (4). Columns $\left(5^{*}\right)$ to $(8)$ are the Hausman-Taylor fixed effects models. Column $\left(5^{*}\right)$ are the estimates of the time-varying covariates that are common across the Hausman-Taylor models. Columns (5) and (6) are the HT models that assume that $S$ and $S \cdot q$ are exogenous while Columns (7) and (8) are the HT/IV models where the potential endogeneity of $S$ and $S \cdot q$ is addressed by applying the instrumental variables approach described above.

$<<<$ Tables 2 and 3 About Here $>>>$

Before turning to the estimated rates of return to schooling, it is important to note that there are no "surprises" in Table 2 with respect to the non-schooling variables. The wageexperience profiles are upwards sloping and concave, suggesting (as expected) that wages increase with experience but at a diminishing rate. Wages appear to vary by place of birth. Men with self-reported poor health have lower wages. There appears to be a marriage premium with married men having higher wages compared to non-married men. Wages also vary considerably by region of residence. It is also important to note (as expected) that the effect of these variables are generally smaller in the fixed effects models compared to the non-fixed effects model. The exception to this generalisation is work experience, with the return to work experience being much higher in the fixed effects models compared to the non-fixed effects models.

Turning to the estimated rates of return to schooling (Table 3), OLS estimation suggests that the rate of return to schooling, when no distinction is made between private and state schooling, is 7.8 per cent [Column (1)]. When this distinction is made, OLS estimation suggests that the rate of return to private schooling is higher at 8.4 per cent compared to 7.5 per cent for state schooling - a statistically significant difference of 11.7 per cent [Column (2)]. The corresponding IV estimates are much larger. When no distinction is made, the rate of return increases to 15.1 per cent which is nearly double the OLS estimate [i.e. compare Column (3) with 
Column (1)]. However, when the distinction between private and state schooling is made, the IV point estimates suggest a rate of return to private schooling of 15.3 per cent compared to 13.2 per cent for state schooling — a percentage difference of 16.2 per cent [Column (4)]. Again, the IV estimates are much larger than the corresponding OLS estimates [i.e. compare Column (4) with Column (2)]. However, the parameter of $S \cdot q$ is not well determined, with a t-statistic of only 1.3 [see Column (4) in Table 2], suggesting on strict statistical criteria there is no difference between state and private schooling .

The rates of return based on the Hausman and Taylor estimation method suggest that when no distinction is made between private and state schooling, and schooling is assumed exogenous, the rate of return is 9.7 percent [Column (5)], which is higher than the OLS estimate of 7.8 per cent [Column (1)]. However, when this distinction is made, the rate of return to private schooling is 10.4 per cent compared to 9.4 percent for state schooling-a statistically significant difference of 10 per cent [Column (6)]. Both these estimates are higher than their corresponding OLS estimates [Column (2)].

When the exogeneity assumption is relaxed, and no distinction is made between private and state schooling, the HT/IV estimates suggest a rate of return to schooling of 18.8 per cent [Column (7)], which is higher than the corresponding OLS [Column (1)], IV [Column (3)] and HT [Column (5)] estimates. When the distinction is made, HT/IV estimates suggest that the rate of return to private schooling is 18.8 per cent compared to 20.0 percent for state schooling. That is, the point estimate of the rate of return to private schooling is lower than for state schooling. Again the parameter of $S \cdot q$ is not well determined, with a t-statistic of only 0.6 [see Column (8) in Table 2], suggesting on strict statistical criteria there is no difference between state and private schooling. 
In summary, taken as a whole the estimates support two broad findings. First, compared to OLS estimation, fixed effects and instrumental variable estimation lead to higher estimates of the rate of return to schooling. This is consistent with the view that OLS seriously under-estimates the rate of return to schooling [see Harmon and Walker (1995) for UK evidence]. Second, when schooling and school quality is assumed exogenous, the rate of return to private schooling is higher than the rate of return to state schooling. However, when this assumption is relaxed, there is little if any difference.

\section{Concluding Comment}

The purpose of this paper was to examine the relationship between school quality and earnings by attempting to evaluate the impact that private schooling has on earnings in Great Britain. As a general remark, the analysis does not provide evidence in support of the hypothesis that the rate of return to private schooling is higher than the rate of return to state schooling. The estimated rates of return are somewhat dependent on the method of estimation used. However, the analysis does support the view that OLS under-estimates the rate of return to schooling by a significant margin. In terms of the school quality debate, the analysis carried out in this paper suggests that school quality does not have an impact of the rate of return to schooling. 


\section{References}

Behrman, J.R. and N. Birdsall (1983) "The Quality of Schooling: Quantity Alone is Misleading." American Economic Review, vol. 73, pp. 928-946.

Betts, J. (1995) "Does School Quality Matter? Evidence from the National Longitudinal Survey of Youth.” Review of Economics and Statistics, vol. 77, pp. 231-250.

Bound, J., D. Jaeger and R. Baker (1995) "Problems with Instrumental Variables Estimation When the Correlation Between the Instruments and the Endogenous Explanatory Variable is Weak." Journal of the American Statistical Association, vol. 90, no. 430, pp. 443-450.

Buck, N., J. Gershuny, D. Rose and J. Scott (1994) Changing Households: The British Household Panel Survey. Colchester : ESRC Centre for Micro-social Change, University of Essex .

Card, D. and A. Krueger (1992a) "Does School Quality Matter: Returns to Education and the Characteristics of Public Schools in the United States." Journal of Political Economy, vol. 100, no. 1, pp. 1-40.

Card, D. and A. Krueger (1992b) "School Quality and Black-White Relative Earnings: A Direct Assessment." Quarterly Journal of Economics, vol. 107, pp. 151-200.

Coleman, J., E. Campbell, C. Hobson, J. McPartland, A. Mood, F. Weinfeld and R. York (1966) Equality of Educational Opportunity. Washington: Government Printing Office.

Hanushek, E.A., S.G. Rivkin and L.L. Taylor (1996) "Aggregation and the Estimated Effects of School Resources." Review of Economics and Statistics, vol. 78, no. 4, pp. 611-627.

Harmon, C. and I. Walker (1995) "Estimates of the Economic Return to Schooling for the United Kingdom.” American Economic Review, vol. 85, no. 5, pp. 1278-1286. 
Hausman, J. and W. Taylor (1981) "Panel Data and Unobservable Fixed Effects.” Econometrica, vol. 49, no. 6, pp. 1377-1398.

Heckman, J., A. Layne-Farrar and P. Todd (1996) "Human Capital Pricing Equations with an Application to Estimating the Effect of Schooling Quality on Earnings." Review of Economics and Statistics, vol. 78, no. 4, pp. 562-610.

Kim, M-K and S.W. Polachek (1994) "Panels Estimates of Male-female Earnings Functions." Journal of Human Resources, vol. 29, no. 2, pp. 406-28.

Mincer, J. (1974) Schooling, Experience and Earnings. New York: National Bureau of Economic Research and Columbia University Press.

Moffitt, R.A. (1996) "Symposium on School Quality and Educational Outcomes: Introduction." Review of Economics and Statistics, vol. 78, no. 4, pp. 559-561.

Prandy, K. (1990) “The Revised Cambridge Scale of Occupations.” Sociology, vol. 24, no. 4, pp. 629-655.

Willis, R. (1986) "Wage Determinants: A Survey and Reinterpretation of Human Capital Earnings Functions." In: O. Ashenfelter and R. Layard (eds.), Handbook of Labor Economics. Amsterdam: North Holland. 


\begin{tabular}{|c|c|c|c|c|c|}
\hline \multicolumn{6}{|c|}{$\begin{array}{c}\text { Table 1 } \\
\text { Descriptive Statistics } \\
\text { (Means/Standard Deviations) }\end{array}$} \\
\hline & & & & & \\
\hline & & & Wave & & \\
\hline Variable: & 1 & 2 & 3 & 4 & 5 \\
\hline Years of schooling $\left(S_{i}\right)$ & $\begin{array}{l}12.8 \\
(3.0)\end{array}$ & -- & -- & -- & -- \\
\hline $\begin{array}{l}\text { Has private schooling } \\
\left(q_{i}=1\right)\end{array}$ & $5.7 \%$ & -- & -- & -- & -- \\
\hline \multicolumn{6}{|l|}{ Place of birth } \\
\hline England & $80.8 \%$ & -- & -- & -- & -- \\
\hline Wales & $3.7 \%$ & -- & -- & -- & -- \\
\hline Scotland & $8.9 \%$ & -- & -- & -- & -- \\
\hline Foreign-born & $6.5 \%$ & -- & -- & -- & -- \\
\hline $\begin{array}{l}\text { Years of work experience } \\
\left(\operatorname{Exp}_{i t}\right)\end{array}$ & 19.2 & 20.1 & 21.1 & 22.1 & 23.2 \\
\hline Poor health $\left(\right.$ Health $\left._{i t}=1\right)$ & $2.9 \%$ & $3.0 \%$ & $2.7 \%$ & $3.3 \%$ & $3.4 \%$ \\
\hline Married (Married $\left._{i t}=1\right)$ & $69.8 \%$ & $71.3 \%$ & $73.3 \%$ & $73.9 \%$ & $74.6 \%$ \\
\hline \multicolumn{6}{|l|}{ Region of residence ${ }_{i t}$} \\
\hline London & $10.2 \%$ & $10.1 \%$ & $10.1 \%$ & $9.7 \%$ & $9.6 \%$ \\
\hline South West & $9.9 \%$ & $9.8 \%$ & $9.8 \%$ & $9.7 \%$ & $9.7 \%$ \\
\hline South East & $19.2 \%$ & $19.3 \%$ & $19.4 \%$ & $19.7 \%$ & $19.5 \%$ \\
\hline East Anglia & $4.5 \%$ & $4.5 \%$ & $4.5 \%$ & $4.5 \%$ & $4.6 \%$ \\
\hline East Midlands & $7.3 \%$ & $7.5 \%$ & $7.4 \%$ & $7.4 \%$ & $7.3 \%$ \\
\hline West Midlands & $9.2 \%$ & $9.2 \%$ & $9.3 \%$ & $9.5 \%$ & $9.4 \%$ \\
\hline North West & $10.8 \%$ & $10.7 \%$ & $10.7 \%$ & $10.8 \%$ & $10.9 \%$ \\
\hline Yorkshire & $9.2 \%$ & $9.1 \%$ & $9.2 \%$ & $9.1 \%$ & $9.1 \%$ \\
\hline North & $7.6 \%$ & $7.6 \%$ & $7.5 \%$ & $7.4 \%$ & $7.5 \%$ \\
\hline Wales & $4.4 \%$ & $4.6 \%$ & $4.5 \%$ & $4.7 \%$ & $4.7 \%$ \\
\hline Scotland & $7.7 \%$ & $7.7 \%$ & $7.8 \%$ & $7.7 \%$ & $7.6 \%$ \\
\hline Hourly wage rate $\left(w_{i t}\right)$ & $\begin{array}{l}8.26 \\
(4.4) \\
\end{array}$ & $\begin{array}{l}8.60 \\
(4.8) \\
\end{array}$ & $\begin{array}{l}8.75 \\
(5.1) \\
\end{array}$ & $\begin{array}{l}9.02 \\
(5.7) \\
\end{array}$ & $\begin{array}{l}9.09 \\
(5.5) \\
\end{array}$ \\
\hline Standard dev & tions in & arenthese & & & \\
\hline
\end{tabular}


Table 2

Wage Equations

\begin{tabular}{|c|c|c|c|c|c|c|c|c|c|}
\hline Model \#: & (1) & (2) & (3) & (4) & $\left(5^{*}\right)$ & (5) & (6) & (7) & (8) \\
\hline Variables: & $O L S$ & $O L S$ & IV & IV & $F E$ & HT & $H T$ & $H T / I V$ & $H T / I V$ \\
\hline \multicolumn{10}{|l|}{ Fixed $\left(Z_{i}\right)$} \\
\hline$S$ & $\begin{array}{l}0.074 \\
(35.6)\end{array}$ & $\begin{array}{l}0.072 \\
(33.6)\end{array}$ & $\begin{array}{l}0.140 \\
(21.3)\end{array}$ & $\begin{array}{c}0.124 \\
(8.4)\end{array}$ & -- & $\begin{array}{l}0.093 \\
(21.5)\end{array}$ & $\begin{array}{l}0.090 \\
(20.3)\end{array}$ & $\begin{array}{l}0.177 \\
(19.7)\end{array}$ & $\begin{array}{c}0.183 \\
(14.3)\end{array}$ \\
\hline$S q$ & - & $\begin{array}{c}0.008 \\
(4.9)\end{array}$ & -- & $\begin{array}{c}0.018 \\
(1.3)\end{array}$ & -- & -- & $\begin{array}{c}0.009 \\
(2.3)\end{array}$ & -- & $\begin{array}{c}-0.010 \\
(0.6)\end{array}$ \\
\hline \multicolumn{10}{|l|}{ Place of birth: } \\
\hline Wales & $\begin{array}{c}0.111 \\
(3.1)\end{array}$ & $\begin{array}{c}0.119 \\
(3.3)\end{array}$ & $\begin{array}{c}0.119 \\
(3.1)\end{array}$ & $\begin{array}{c}0.137 \\
(3.4)\end{array}$ & -- & $\begin{array}{c}0.024 \\
(0.4)\end{array}$ & $\begin{array}{c}0.033 \\
(0.5)\end{array}$ & $\begin{array}{c}0.017 \\
(0.2)\end{array}$ & $\begin{array}{c}0.008 \\
(0.1)\end{array}$ \\
\hline Scotland & $\begin{array}{c}-0.065 \\
(2.0)\end{array}$ & $\begin{array}{c}-0.062 \\
(1.9)\end{array}$ & $\begin{array}{c}-0.051 \\
(1.5)\end{array}$ & $\begin{array}{c}-0.047 \\
(1.4)\end{array}$ & -- & $\begin{array}{c}0.057 \\
(1.3)\end{array}$ & $\begin{array}{c}0.062 \\
(1.4)\end{array}$ & $\begin{array}{c}0.043 \\
(0.9)\end{array}$ & $\begin{array}{c}0.037 \\
(0.8)\end{array}$ \\
\hline Foreign & $\begin{array}{c}-0.045 \\
(1.9)\end{array}$ & $\begin{array}{c}-0.048 \\
(2.0)\end{array}$ & $\begin{array}{c}-0.088 \\
(3.39\end{array}$ & $\begin{array}{c}-0.087 \\
(3.3)\end{array}$ & -- & $\begin{array}{c}0.022 \\
(0.4)\end{array}$ & $\begin{array}{c}0.018 \\
(0.3)\end{array}$ & $\begin{array}{c}-0.082 \\
(1.5)\end{array}$ & $\begin{array}{c}-0.081 \\
(1.5)\end{array}$ \\
\hline \multicolumn{10}{|l|}{ Time-varying $\left(X_{i t}\right)$} \\
\hline Exp & $\begin{array}{l}0.029 \\
(12.1)\end{array}$ & $\begin{array}{l}0.029 \\
(12.4)\end{array}$ & $\begin{array}{l}0.030 \\
(11.7)\end{array}$ & $\begin{array}{l}0.031 \\
(11.6)\end{array}$ & $\begin{array}{l}0.049 \\
(11.0)\end{array}$ & -- & -- & -- & -- \\
\hline $\operatorname{Exp}^{2} / 1000$ & $\begin{array}{c}-0.495 \\
(9.9)\end{array}$ & $\begin{array}{l}-0.507 \\
(10.2)\end{array}$ & $\begin{array}{c}-0.386 \\
(7.1)\end{array}$ & $\begin{array}{c}-0.432 \\
(6.6)\end{array}$ & $\begin{array}{c}-0.667 \\
(7.2)\end{array}$ & -- & -- & -- & -- \\
\hline Health & $\begin{array}{c}-0.095 \\
(2.8)\end{array}$ & $\begin{array}{c}-0.096 \\
(2.8)\end{array}$ & $\begin{array}{c}-0.106 \\
(2.9) \\
\end{array}$ & $\begin{array}{c}-0.108 \\
(3.0) \\
\end{array}$ & $\begin{array}{c}-0.015 \\
(0.7)\end{array}$ & -- & -- & -- & -- \\
\hline Married & $\begin{array}{c}0.118 \\
(8.2) \\
\end{array}$ & $\begin{array}{c}0.116 \\
(8.1) \\
\end{array}$ & $\begin{array}{l}0.111 \\
(7.2) \\
\end{array}$ & $\begin{array}{l}0.108 \\
(7.0) \\
\end{array}$ & $\begin{array}{c}0.025 \\
(1.3) \\
\end{array}$ & -- & -- & -- & -- \\
\hline \multicolumn{10}{|l|}{ Region: } \\
\hline South West & $\begin{array}{c}-0.182 \\
(6.9)\end{array}$ & $\begin{array}{c}-0.174 \\
(6.6)\end{array}$ & $\begin{array}{c}-0.093 \\
(3.1)\end{array}$ & $\begin{array}{c}-0.089 \\
(3.0)\end{array}$ & $\begin{array}{c}0.144 \\
(1.5)\end{array}$ & -- & -- & -- & -- \\
\hline South East & $\begin{array}{c}-0.056 \\
(2.5)\end{array}$ & $\begin{array}{c}-0.049 \\
(2.1)\end{array}$ & $\begin{array}{c}-0.031 \\
(1.2)\end{array}$ & $\begin{array}{c}-0.019 \\
(0.7)\end{array}$ & $\begin{array}{c}0.028 \\
(0.4)\end{array}$ & -- & -- & -- & -- \\
\hline East Anglia & $\begin{array}{c}-0.244 \\
(7.3)\end{array}$ & $\begin{array}{c}-0.248 \\
(7.5)\end{array}$ & $\begin{array}{c}-0.194 \\
(5.4)\end{array}$ & $\begin{array}{c}-0.210 \\
(5.5)\end{array}$ & $\begin{array}{c}-0.002 \\
(0.1)\end{array}$ & -- & -- & -- & - \\
\hline East Midlands & $\begin{array}{c}-0.213 \\
(7.4)\end{array}$ & $\begin{array}{c}-0.207 \\
(7.2)\end{array}$ & $\begin{array}{c}-0.089 \\
(2.7)\end{array}$ & $\begin{array}{c}-0.094 \\
(2.8)\end{array}$ & $\begin{array}{c}-0.019 \\
(0.2)\end{array}$ & -- & -- & -- & -- \\
\hline West Midlands & $\begin{array}{l}-0.275 \\
(10.2)\end{array}$ & $\begin{array}{c}-0.265 \\
(9.9)\end{array}$ & $\begin{array}{c}-0.197 \\
(6.6)\end{array}$ & $\begin{array}{c}-0.187 \\
(6.1)\end{array}$ & $\begin{array}{c}-0.105 \\
(0.8)\end{array}$ & -- & -- & -- & -- \\
\hline North West & $\begin{array}{c}-0.205 \\
(7.9) \\
\end{array}$ & $\begin{array}{c}-0.198 \\
(7.7) \\
\end{array}$ & $\begin{array}{c}-0.168 \\
(6.1)\end{array}$ & $\begin{array}{c}-0.159 \\
(5.5) \\
\end{array}$ & $\begin{array}{c}-0.040 \\
(0.4)\end{array}$ & -- & -- & -- & -- \\
\hline Yorkshire & $\begin{array}{c}-0.259 \\
(9.6)\end{array}$ & $\begin{array}{c}-0.250 \\
(9.2)\end{array}$ & $\begin{array}{c}-0.177 \\
(5.9)\end{array}$ & $\begin{array}{c}-0.171 \\
(5.7)\end{array}$ & $\begin{array}{c}0.106 \\
(0.7)\end{array}$ & -- & -- & -- & -- \\
\hline North & $\begin{array}{c}-0.220 \\
(7.7)\end{array}$ & $\begin{array}{c}-0.212 \\
(7.5)\end{array}$ & $\begin{array}{c}-0.140 \\
(4.5)\end{array}$ & $\begin{array}{c}-0.134 \\
(4.2)\end{array}$ & $\begin{array}{c}0.106 \\
(0.7)\end{array}$ & -- & -- & -- & -- \\
\hline Wales & $\begin{array}{c}-0.333 \\
(9.1)\end{array}$ & $\begin{array}{c}-0.329 \\
(9.0)\end{array}$ & $\begin{array}{c}-0.241 \\
(6.0)\end{array}$ & $\begin{array}{c}-0.248 \\
(6.1)\end{array}$ & $\begin{array}{c}0.128 \\
(1.0)\end{array}$ & -- & -- & -- & -- \\
\hline Scotland & $\begin{array}{c}-0.224 \\
(5.8) \\
\end{array}$ & $\begin{array}{c}-0.214 \\
(5.5) \\
\end{array}$ & $\begin{array}{c}-0.191 \\
(4.6) \\
\end{array}$ & $\begin{array}{c}-0.174 \\
(4.0) \\
\end{array}$ & $\begin{array}{c}-0.162 \\
(1.1)\end{array}$ & -- & -- & -- & -- \\
\hline Constant & $\begin{array}{c}0.846 \\
(19.9) \\
\end{array}$ & $\begin{array}{l}0.862 \\
(20.2) \\
\end{array}$ & $\begin{array}{c}-0.125 \\
(1.2) \\
\end{array}$ & $\begin{array}{c}0.076 \\
(0.4) \\
\end{array}$ & -- & $\begin{array}{c}0.148 \\
(2.6) \\
\end{array}$ & $\begin{array}{c}0.173 \\
(3.0) \\
\end{array}$ & $\begin{array}{c}-0.927 \\
(8.0) \\
\end{array}$ & $\begin{array}{c}-0.985 \\
(6.5) \\
\end{array}$ \\
\hline$R^{2}(\%)$ & 27.7 & 28.0 & 17.5 & 17.5 & 87.2 & 30.7 & 31.0 & 27.0 & 27.1 \\
\hline$N(o b s)$ & 5,370 & 5,370 & 5,370 & 5,370 & 5,370 & 1,074 & 1,074 & 1,074 & 1,074 \\
\hline$N($ individuals) & 1,074 & 1,074 & 1,074 & 1,074 & 1,074 & 1,074 & 1,074 & 1,074 & 1,074 \\
\hline
\end{tabular}


Table 3

Estimated Rates of Return to Schooling (Per cent)

\begin{tabular}{|l|c|c|c|c|c|c|c|c|}
\hline $\begin{array}{l}\text { Estimate } \\
\text { based on } \\
\text { Eq. \# }\end{array}$ & $(\mathbf{1})$ & $\mathbf{( 2 )}$ & $\mathbf{( 3 )}$ & $\mathbf{( 4 )}$ & $\mathbf{( 5 )}$ & $\mathbf{( 6 )}$ & $\mathbf{( 7 )}$ & $\mathbf{( 8 )}$ \\
\hline & OLS & OLS & IV & IV & HT & HT & HT/IV & HT/IV \\
\hline & & & & & & & & \\
\hline $\boldsymbol{r}$ & 7.8 & -- & 15.1 & -- & 9.7 & -- & 18.8 & - \\
\hline $\boldsymbol{r}_{\boldsymbol{s}}$ & -- & 7.5 & -- & 13.2 & -- & 9.4 & -- & 20.0 \\
\hline $\boldsymbol{r}_{\boldsymbol{p}}$ & -- & 8.4 & -- & 15.3 & -- & 10.4 & -- & 18.8 \\
\hline & & & & & & & & \\
\hline $\boldsymbol{r}_{\boldsymbol{p}}-\boldsymbol{r}_{\boldsymbol{s}}$ & -- & 0.9 & -- & 2.1 & -- & 0.9 & -- & -1.2 \\
\hline$\left.\left(\boldsymbol{r}_{p}-\boldsymbol{r}_{s}\right) / \boldsymbol{r}_{s}\right) \mathbf{1 0 0}$ & -- & 11.7 & -- & 16.2 & -- & 10.0 & -- & -6.0 \\
\hline & & & & & & & & \\
\hline & & & & & & & & \\
\hline
\end{tabular}


Figure 1

Experience-Earnings Profiles

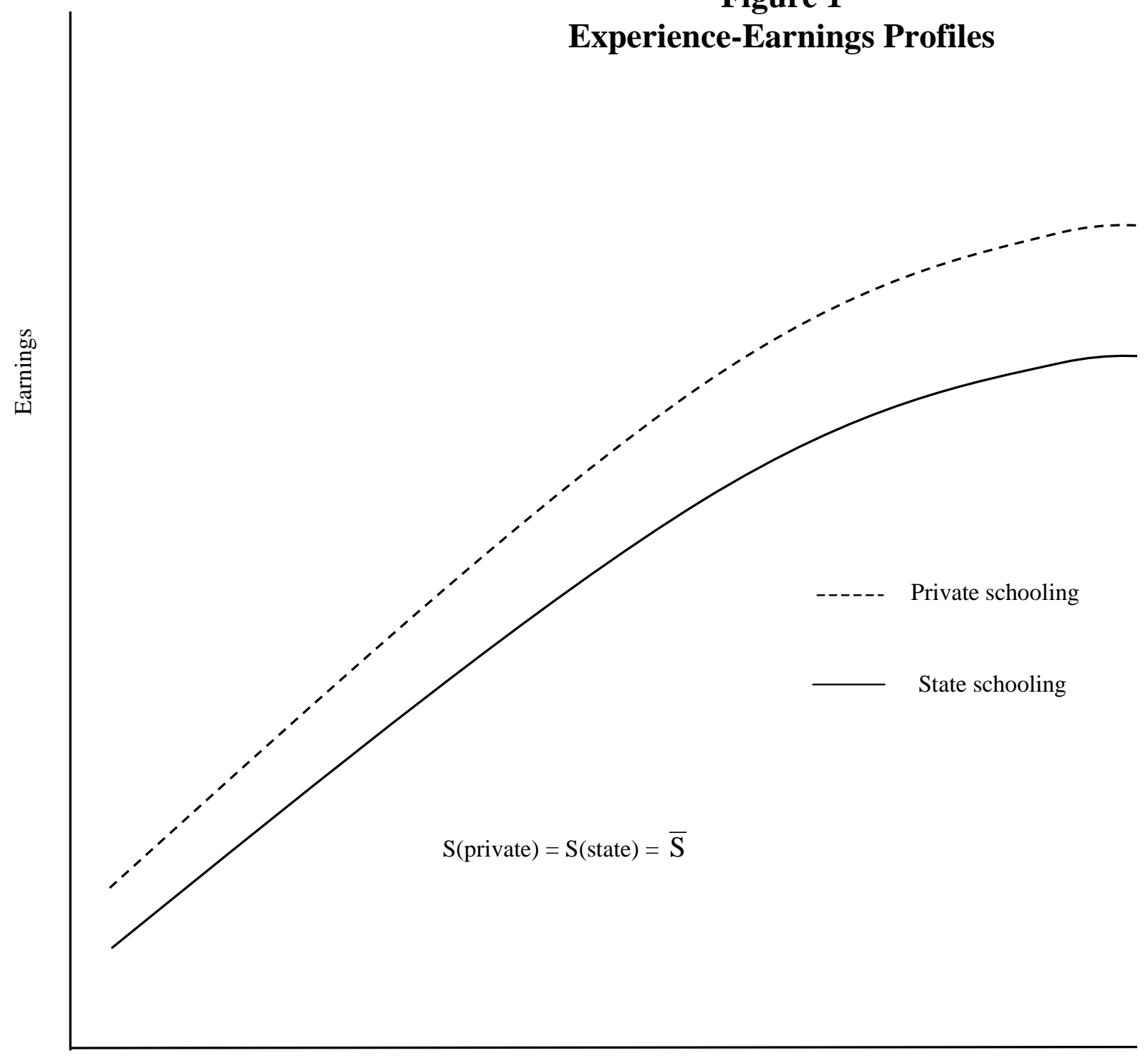

Experience 